\title{
Chemokine receptor CXCR3 is important for lung tissue damage and airway remodeling induced by short-term exposure to cigarette smoking in mice
}

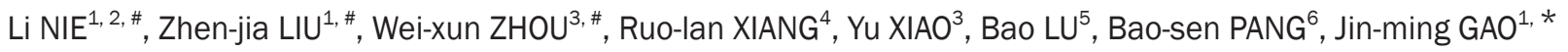 \\ ${ }^{1}$ Department of Respiratory Diseases, Peking Union Medical College Hospital, Chinese Academy of Medical Sciences \& Peking Union \\ Medical College, Beijing 100730, China; ${ }^{2}$ Department of Respiratory Diseases, West China Hospital, Sichuan University, Chengdu \\ 610041, China; ${ }^{3}$ Department of Pathology, Peking Union Medical Hospital, Chinese Academy of Medical Sciences \& Peking Union \\ Medical College, Beijing 100730, China; ${ }^{4}$ Department of Physiology and Pathophysiology, Peking University Health Sciences Center, \\ Beijing 100191, China; ${ }^{5}$ Ina Sue Perlmutter Laboratory, Division of Pulmonary, Children's Hospital, Harvard Medical School, Boston, \\ MA 02115, USA; ${ }^{\circ}$ Institute of Respiratory Diseases, Chaoyang Hospital, Capital Medical University, Beijing 100020, China
}

\begin{abstract}
Aim: To investigate the role of chemokine receptor CXCR3 in cigarette smoking (CS)-induced pulmonary damage.
Methods: CXCR3 knockout (CXCR3-/-) mice were used. Differences in airspace enlargement, mRNA expression of matrix metalloproteinases (MMPs), transforming growth factor (TGF) $\beta 1$, CXCL10 in lung homogenates, and CXCL10 content in bronchoalveolar lavage (BAL) fluids and homogenates were compared between CXCR3-/- mice and wild-type (WT) mice three days after three-day CS exposures. Results: The linear intercept was significantly less in CXCR3-/- mice than in WT mice (30.1 $\pm 0.9 \mu \mathrm{m} v \mathrm{vs} 40.3 \pm 2.4 \mu \mathrm{m}, P<0.01)$. Morphologically, collagen was deposited less around airways and vessels in CXCR3-/- mice. The lung hydroxyproline content was significantly lower in CXCR3-/- mice than in WT mice $(6.0 \pm 1.0 \mu \mathrm{g} / \mathrm{mL}$ vs $12.0 \pm 1.6 \mu \mathrm{g} / \mathrm{mL}, P<0.05)$. Profoundly lower mRNA expression of MMP2, MMP12, TGFß1, and CXCL10 was seen in lung homogenates from CXCR3-/- mice. CXCL10 concentrations in BAL fluid and lung homogenates were significantly lower in CXCR3-/- mice than in WT mice (BAL fluid: $19.3 \pm 1.4 \mathrm{pg} / \mathrm{mL}$ vs $24.8 \pm 1.6 \mathrm{pg} / \mathrm{mL}, P<0.05$; lung homogenates: $76.6 \pm 7.0 \mathrm{pg} / \mathrm{mL}$ vs $119.5 \pm 15.9 \mathrm{pg} / \mathrm{mL}, P<0.05)$.

Conclusion: CXCR3 is important in mediating lung tissue damage and airway remodeling following a short-term CS insult, possibly through up-regulation of CXCL10 and inducement of mRNA expression of MMPs. Targeting CXCR3 may be helpful for prevention of CSinduced pulmonary pathology.
\end{abstract}

Keywords: CXCR3; CXCL10; cigarette smoking; tissue damage; airway remodeling

Acta Pharmacologica Sinica (2010) 31: 436-442; doi: 10.1038/aps.2009.192; published online 8 Mar 2010

\section{Introduction}

Cigarette smoking (CS) is an established risk factor for the inception of chronic obstructive pulmonary disease (COPD), which is pathologically characterized by pulmonary tissue damage manifested by airspace enlargement and excessive collagen deposition in the small airways of $<2 \mathrm{~mm}$ in diameter, termed airway remodeling ${ }^{[1,2]}$. It has become apparent that these two pathological alterations can be found in many patients with $\mathrm{COPD}^{[2]}$. Niewoehner and coworkers demonstrated that early structural changes in the small airways

\footnotetext{
\# These authors contributed equally to this work.

* To whom correspondence should be addressed.

E-mail gaojm@pumch.cn

Received 2009-08-21 Accepted 2009-12-07
}

existed even before the establishment of COPD ${ }^{[3]}$. Subsequent studies consistently showed that small airway remodeling was pivotal in causing airflow limitation in patients with $\mathrm{COPD}^{[4-6]}$. However, the underlying mechanisms of remodeling remain unclear.

The roles of chemokines via their respective receptors in the pathogenesis of COPD have been extensively addressed elsewhere $^{[7-9]}$. For example, CXCL9, and CXCL10, and CXCL11 and CCL5, ligands for CXCR3 and CCR5, respectively, were shown to be elevated in sputum from COPD patients ${ }^{[10]}$. An antagonist of CXCR2 has been shown to abrogate lung neutrophilic inflammation in rodent models of CS exposure ${ }^{[11]}$. Lung tissue inflammation and emphysema induced by CS were significantly decreased in both CCR5-/- and CCR6-/- mice through the decreased release of macrophage inflammatory 
proteins: (MIP)-1a, MIP-1 $\beta$, CXCL10, and MIP-3a ${ }^{[7,8]}$.

Accumulating evidence has suggested that CXCR3-CXCL10 interactions play a pivotal role in the inception and progression of COPD via recruitment of CD8+ T cells into airways and lung parenchyma ${ }^{[12,13]}$. CXCR3 and its specific ligand CXCL10/interferon-inducible protein-10 (IP-10) were abundantly expressed in bronchiolar epithelial cells and airway smooth muscle cells. CD8+ T cells expressing CXCR3 in epithelium and submucosa in smokers with COPD were increased $^{[14]}$. Our recent studies documented that CXCR3 is involved in acute pulmonary inflammation induced by shortterm exposure of CS through recruitment of CD8+ T cells into lung and in the release of CXCL10/interferon $\gamma$-inducible protein (IP)- $10^{[15,16]}$. Given the importance of CXCR3 in attracting inflammatory cells into lung, we thus hypothesized that CXCR3 and CXCL10/IP-10 might be important for the pulmonary damage induced by short-term exposure to CS, in particular, lung connective tissue breakdown and airway remodeling. We have addressed this hypothesis by using CXCR3 knockout mice exposed to CS for three consecutive days.

\section{Materials and methods}

\section{Mice and cigarette smoke exposure}

Mice deficient in the CXCR3 gene have been established by gene targeting as described elsewhere ${ }^{[17]}$. CXCR3 KO mice and WT littermate mice (Experimental Animal Research Center, Beijing, China) with C57BL/ 6 background (backcross $>14$ generations) were maintained in a pathogen-free mouse facility at the Peking Union Medical College Animal Care Center. Clean food and water were supplied with free access. Mice aged 10-12 weeks (about 20-22 g in weight) were used in the experiments.

A commercially available filter cigarette was used (White Shark brand, Hunan Tobacco Company, China) and, according to the manufacturer's specification, each cigarette contained 1 $\mathrm{mg}$ of nicotine and $13 \mathrm{mg}$ of tar. CS exposure was performed according to previously described protocols ${ }^{[15,16,18,19]}$. Briefly, the mice ( $n=8$ per group) were placed in a closed plastic box connected to a smoke generator, and they received wholebody exposure to the tobacco smoke of five cigarettes four times a day with 30-min smoke free intervals for three consecutive days. Control mice received filtered air according to the same procedure. Animals were sacrificed three days after the last CS exposure by pentobarbital overdose.

All experiments were conducted according to international and institutional guidelines for animal care and approved by Peking Union Medical College Hospital Committee on the Animal Care and Use.

\section{Histological analysis of lung tissue}

The mice were killed, and the lungs were inflated with $25 \mathrm{~mL}$ $\mathrm{H}_{2} \mathrm{O}$ with $10 \%$ formalin and fixed overnight, embedded in paraffin, and sectioned at $5 \mu \mathrm{mol} / \mathrm{L}$. The sections were stained with hematoxylin and eosin for routine histology examined by light microscopy. Mature collagen deposited around small airways and vessels was stained using the standard Masson trichrome method.

The mean linear intercept (Lm), which is the average distance between alveolar walls, reflects enlargement of alveolar spaces. Quantification of Lm was done by light microscopy by two blinded investigators according to previously described methods ${ }^{[7,8]}$. Briefly, the Lm was measured by placing a $100 \times 100-\mu \mathrm{m}$ grid on each field. The total length of each line of the grid divided by the number of alveolar intercepts generates the average distance between alveolated surfaces. Histopathological assessment on small airway remodeling and inflammatory response in the lung was performed in a blind manner by Dr Wei-xun ZHOU.

\section{Bronchoalveolar lavage (BAL) and lung homogenates}

Mice were sacrificed, and the tracheas were cannulated by using a 20-gauge catheter. BAL was performed twice with 0.8 $\mathrm{mL}$ of ice-cold PBS ( $\mathrm{pH}$ 7.4) each. The BAL fluid was spun at $1500 \mathrm{rpm}$ for $5 \mathrm{~min}$ at $4{ }^{\circ} \mathrm{C}$, and the supernatant was collected and stored at $-70{ }^{\circ} \mathrm{C}$ until analyzed.

Animals were euthanized and perfused with $3 \mathrm{~mL}$ of cold saline via the heart. The left lobes were removed and homogenized in $1 \mathrm{~mL}$ of PBS containing a complete protease inhibitor cocktail (Sigma). Then, the samples were centrifuged for $10 \mathrm{~min}$ at $3000 \mathrm{rpm}$. Supernatants were filtered through a $0.45-\mu \mathrm{m}$ filter and kept at $-70{ }^{\circ} \mathrm{C}$ until used.

\section{Hydroxyproline assay}

Total lung collagen was determined by analysis of hydroxyproline as previously described with minor modification ${ }^{[20]}$. Briefly, lungs were harvested at three days after CS exposure and homogenized in $2 \mathrm{~mL}$ of PBS ( $\mathrm{pH} 7.4$ ). A dose of $0.5 \mathrm{~mL}$ of each sample was then digested with $0.5 \mathrm{~mL}$ of $12 \mathrm{~mol} / \mathrm{L}$ $\mathrm{HCl}$ at $120{ }^{\circ} \mathrm{C}$ overnight. $5 \mu \mathrm{L}$ of citrate/acetate buffer $(5 \%$ citric acid, $7.24 \%$ sodium acetate, $3.4 \%$ sodium hydroxide, and $1.2 \%$ glacial acetic acid, $\mathrm{pH} 6.0$ ) and $100 \mu \mathrm{L}$ of chlomine$\mathrm{T}$ solution (282 $\mathrm{mg}$ chloramines-T, $2 \mathrm{~mL} n$-propanol, $2 \mathrm{~mL}$ $\mathrm{H}_{2} \mathrm{O}$, and $16 \mathrm{~mL}$ citrate/acetate buffer) were added to $5 \mu \mathrm{L}$ of the sample at room temperature for $20 \mathrm{~min}$. Then $100 \mu \mathrm{L}$ of Ehrlich's solution [2.5 g 4-(dimethylamine) benzaldehyde, 9.3 $\mathrm{mL}$ n-propanol, and $3.9 \mathrm{~mL} \mathrm{70 \%} \mathrm{perchloric} \mathrm{acid]} \mathrm{were} \mathrm{added}$ to each sample, and the samples were incubated for $15 \mathrm{~min}$ at $65{ }^{\circ} \mathrm{C}$. Samples were cooled to room temperature and read at $550 \mathrm{~nm}$. Hydroxyproline standards (Sigma) at concentrations from 0 to $50 \mu \mathrm{g} / \mathrm{mL}$ were used to construct a standard curve.

\section{Determination of protein content in BAL fluid}

Total protein content in BAL fluid was assayed using the BCA Protein Assay Kit (Pierce) according to the manufacturer's instructions.

\section{ELISA analysis of TNF $\alpha$ and CXCL10 in BAL fluid}

The concentrations of TNFa and CXCL10 in BAL fluid and/or lung homogenates were determined by ELISA kits (R\&D systems) according to the manufacturer's recommendations. 
RNA extraction and semi-quantitative RT-PCR analysis

Total RNA was extracted from the lung using TRIzol reagent (Invitrogen) according to the manufacturer's instructions and treated with RNase-free DNase. RNA was reverse-transcribed, and cDNA was subjected to PCR for analyzing the expression of IFNY, CXCL9, CXCL10, CXCL11, metalloproteinase (MMP-2, MMP-9, and MMP-12), a tissue inhibitor of metalloproteinases (TIMPs) $1-4$, and $\beta$-actin. The primers for the PCR are detailed in Table 1.

Table 1. RT-PCR primers, conditions and products.

\begin{tabular}{|c|c|c|c|c|}
\hline $\begin{array}{l}\text { RT-PCR } \\
\text { Genes }\end{array}$ & S/AS & Primer sequence ( $5^{\prime}$ to $\left.3^{\prime}\right)$ & $\begin{array}{l}\mathrm{Tm} \\
\left({ }^{\circ} \mathrm{C}\right)\end{array}$ & $\begin{array}{l}\text { Product } \\
\text { (bp) }\end{array}$ \\
\hline \multirow[t]{2}{*}{ CXCL9 } & S & CTTGGGCATCATCTTCCTG & 55 & 352 \\
\hline & AS & TGAACGACGACGACTTTGG & & \\
\hline \multirow[t]{2}{*}{ CXCL10 } & S & GTCATTTTCTGCСTCATCC & 55 & 273 \\
\hline & AS & GAGCCCTTTTAGACCTTTT & & \\
\hline \multirow[t]{2}{*}{ CXCL11 } & $\mathrm{S}$ & CTGCTCAAGGCTTCCTTATGTT & 55 & 166 \\
\hline & AS & CCTTTGTCGTTTATGAGCCTTC & & \\
\hline \multirow[t]{2}{*}{ TGF- $\beta 1$} & S & СCCTGTATTCCGTCTCCTT & 55 & 363 \\
\hline & AS & GCGGTGCTCGCTTTGTA & & \\
\hline \multirow[t]{2}{*}{ IFN $\beta$} & $\mathrm{S}$ & CATCTTGGCTTTGCAGCTCTT & 55 & 363 \\
\hline & AS & CTGGACCTGTGGGTTGTTGA & & \\
\hline \multirow[t]{2}{*}{ MMP2 } & $S$ & GTGTCACTGTCCGCCAAA & 55 & 397 \\
\hline & AS & GTCCCGAGACCGCTATGT & & \\
\hline \multirow[t]{2}{*}{ MMP9 } & $\mathrm{S}$ & AGCCAACTATGACCAGGA & 55 & 367 \\
\hline & AS & TGCCGTCATTGTCGTCTTTAT & & \\
\hline \multirow[t]{2}{*}{ MMP12 } & $S$ & GTCCTGGTCTGCCTTCTATC & 55 & 532 \\
\hline & AS & TGTGGAATACTATGGTGGTG & & \\
\hline \multirow[t]{2}{*}{ TIMP1 } & $\mathrm{S}$ & GCATCTGGCATCCTCTTGTTG & 55 & 637 \\
\hline & AS & GACAGTGTTCAGGCTTCAGTTTTTC & & \\
\hline \multirow[t]{2}{*}{ TIMP2 } & $\mathrm{S}$ & ACAGGCGTTTTGCAATGCAGAC & 55 & 598 \\
\hline & AS & GCTTTTCAATTGGCCACAGGGGCTC & & \\
\hline \multirow[t]{2}{*}{ TIMP3 } & $\mathrm{S}$ & CTGGCTTGGGCTTGTCGTGCTCCTGA & 55 & 550 \\
\hline & AS & GGGAAGGAGGTGAGGTGGGGCAGGTC & & \\
\hline \multirow[t]{2}{*}{ TIMP4 } & $\mathrm{S}$ & CACGCCATTTGACTCTTCCCT & 55 & 485 \\
\hline & AS & CCAGCAGCCAGTCCGTCCAGA & & \\
\hline \multirow[t]{2}{*}{$\beta$-actin } & $\mathrm{S}$ & СTTCCTTAATGTCACGCACGATTTC & 55 & 541 \\
\hline & AS & GTGGGGCGGCCCAGGCACCA & & \\
\hline
\end{tabular}

S, sense; AS, antisense

\section{Statistical analysis}

Data are expressed as mean \pm SEM. Where appropriate, comparisons among groups were carried out using ANOVA followed by an unpaired Student's t-test (two-tailed) using GraphPad PRISM software (Version 4.0 for Windows; GraphGrad, San Diego, CA). A value of $P<0.05$ was set as the threshold for significance.

\section{Results}

CS-induced airspace enlargement is partially alleviated in CXCR3-/- mice

Destruction of intricate alveolar architecture is manifested by enlarged alveolar spaces ${ }^{[21]}$. To evaluate the difference in enlargement of alveolar spaces between CXCR3-/- mice and WT mice after short-term CS insult, we measured the linear intercept, Lm, which reflects the average distance between alveolar walls and parallels the degree of emphysema ${ }^{[12]}$.

No obvious inflammation response was noted in CXCR3-/mice; in contrast, CXCR3-/- mice displayed significant alleviation of airspace enlargement in comparison to CXCR3 WT mice at three days after the last CS exposure (Figure 1A). Lm values were significantly reduced in CXCR3-/- mice compared to CXCR3 WT mice $(30.1 \pm 0.9 \mu \mathrm{m}$ vs $40.3 \pm 2.4 \mu \mathrm{m}, P<0.01$, Figure 1B).

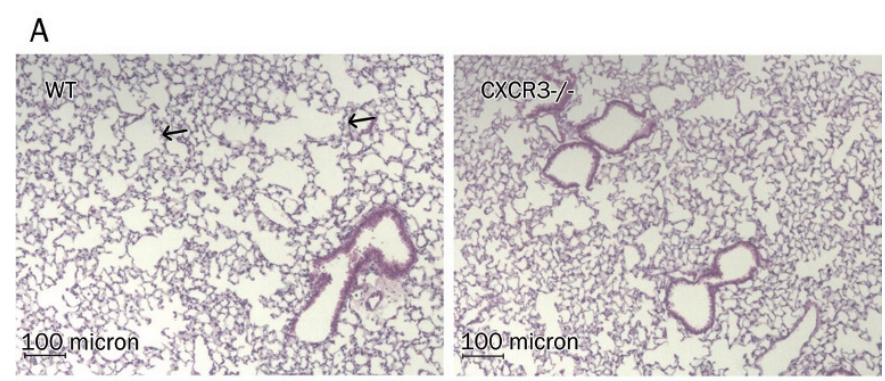

B

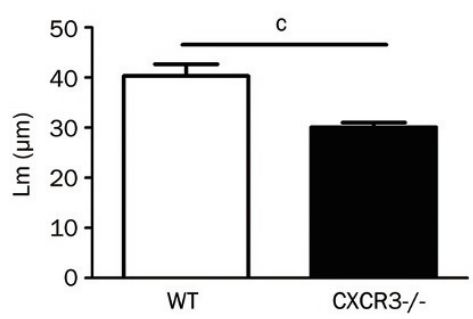

Figure 1. Effect of CXCR3 deletion on airspace enlargement at three days after the last CS exposure. (A) Morphometrical appearance of lungs from CXCR3-/- and WT mice (magnification $\times 40$ ); the arrow points to the enlarged airspace in WT mice. $n=8$ mice/group. (B) Difference in Lm between CXCR3-/- and WT mice. Results are expressed as mean \pm SEM. $n=6$ mice/group, ${ }^{c} P<0.01$.

CXCR3 is required for $\mathrm{MRNA}$ expression of MMPs in lung homogenates upon CS exposure

Lung tissue change is thought to be due to a protease-antiprotease imbalance that favors proteases. Elastin-degrading enzymes, such as MMP2, MMP9, and MMP12, have the capability of facilitating lung destruction ${ }^{[22,23]}$. At three days after short-term CS exposure, there was significantly decreased mRNA expression of MMP2 and MMP12, but not MMP9, in lung homogenates from CXCR3-/- mice relative to CXCR3 WT mice (Figure 2A). In contrast, there was significant elevation of TIMP3 mRNA expression in lung homogenates from CXCR3-/- mice at three days after the final CS exposure (Figure 2B).

CXCL10 at mRNA and protein levels was decreased in CXCR3-/mice

As shown in Figure 3A, mRNA expression of CXCL10, but not 

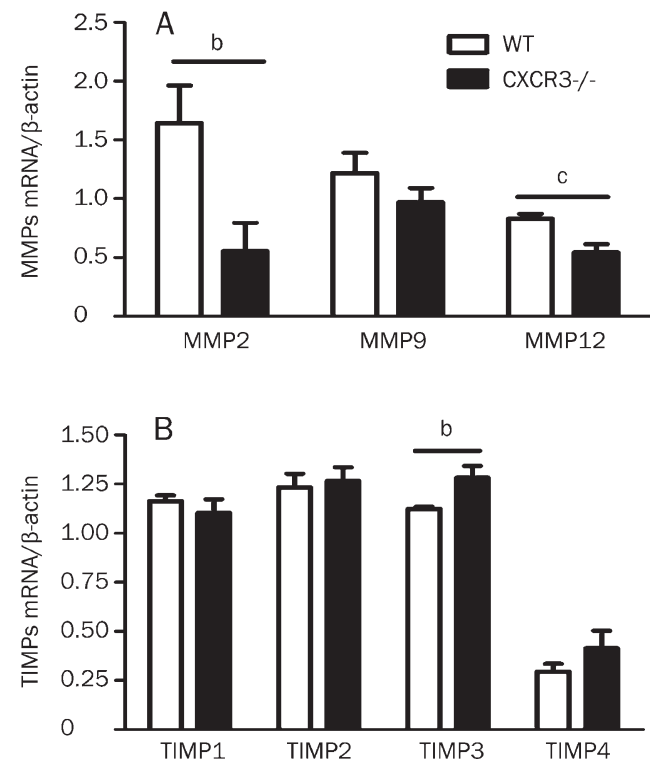

Figure 2. Effect of CXCR3 deficiency on mRNA expression of MMPs and TIMPs in lung homogenates at three days after the last CS exposure. (A) mRNA expression of MMP2, MMP9, and MMP12 in CXCR3-/- and WT mice, $n=5$ animals/group. (B) mRNA expression of TIMPs 1-4 in CXCR3-/and WT mice, $n=8$ animals/group. Results are expressed as mean \pm SEM. ${ }^{\mathrm{b}} P<0.05$.

of CXCL9 and CXCL11, was significantly up-regulated at three days after the last CS exposure in the lung homogenates from WT mice relative to CXCR3-/- mice, although the elevation of expression of IFNY mRNA in lung homogenates showed a trend towards significance in WT mice at three days after CS exposure in comparison to CXCR3 $\mathrm{KO}$ mice $(P=0.07$, Figure 3B). More importantly, the concentration of CXCL10 in both BAL fluid and lung homogenates was consistently and significantly lower in CXCR3 KO mice than in WT mice (BAL fluid: $19.30 \pm 1.36 \mathrm{pg} / \mathrm{mL}$ vs $24.82 \pm 1.57 \mathrm{pg} / \mathrm{mL}, P<0.05$; lung homogenates: $76.6 \pm 7.0 \mathrm{pg} / \mathrm{mL}$ vs $119.5 \pm 15.9 \mathrm{pg} / \mathrm{mL}, P<0.05$ ) (Figure 3C).

\section{Airway remodeling is attenuated in CXCR3-/- mice after CS exposure}

Remodeling of small airways is characterized by thickening of airway walls by means of collagen deposition due to aberrant repair of tissue ${ }^{[2]}$. To investigate the differences in airway remodeling in lungs from CXCR3-/- mice and WT mice in response to short-term exposure of CS, lung sections stained with Masson trichrome were analyzed, and hydroxyproline content in lung was measured. Morphologically, there was less pronounced collagen deposition around small airways and vessels in CXCR3-/- mice (Figure 4A). We biochemically quantified hydroxyproline content unique to fibrosis in lung tissue and found that there was less hydroxyproline content in lung homogenates from CXCR3-/- mice than in WT mice $(6.0 \pm 1.0 \mu \mathrm{g} / \mathrm{mL}$ vs $12.0 \pm 1.6 \mu \mathrm{g} / \mathrm{mL}, P<0.05)$ (Figure $4 \mathrm{~B}$ ). To
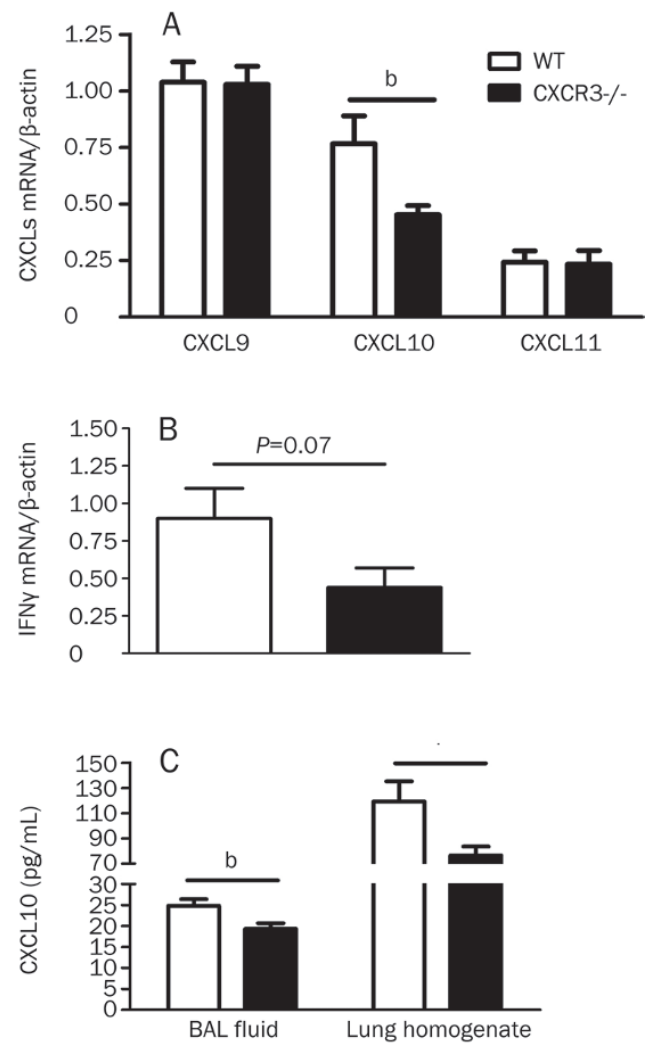

Figure 3. Effect of CXCR3 deletion on mRNA expression in lung homogenates and production of CXCL10/IP-10 in BAL fluid and lung homogenates at three days after short-term CS exposure. (A) mRNA expression of CXCR3 ligands, $n=5$ animals/group. (B) mRNA expression of IFNy, $n=6$ animals/group. (C) CXCL10/IP-10 concentration in BAL fluid and lung homogenates, $n=8$ animals/group. Results are expressed as mean \pm SEM. ${ }^{\mathrm{b}} P<0.05$.

further elucidate the possible molecular mechanism underlying the difference in collagen deposition observed between CXCR3-/- mice and WT mice, we assayed a fibrogenic cytokine, TGF $\beta 1$, at the mRNA level in lung homogenates. Our data revealed that mRNA expression of TGF $\beta 1$ was significantly lower in CXCR3-/- mice relative to WT mice at three days after the last CS exposure (Figure 4C).

\section{Concentration of protein and TNF $\alpha$ in BAL fluid in CXCR3-/- and} WT mice

Protein content in BAL fluid, reflecting pulmonary vascular permeability into alveolar spaces after the mice were administered cigarette smoke, was similar between CXCR3-/- mice and WT mice $(700.9 \pm 64.4 \mu \mathrm{g} / \mathrm{mL}$ vs $642.1 \pm 97.2 \mu \mathrm{g} / \mathrm{mL}$ ) (Figure $5 \mathrm{~A}$ ). Also, there was no significant difference in TNFa concentration in BAL fluid between CXCR3-/- mice and WT mice $(20.9 \pm 0.9 \mathrm{pg} / \mathrm{mL}$ vs $29.4 \pm 5.4 \mathrm{pg} / \mathrm{mL})$ (Figure $5 \mathrm{~B}$ ). There was mild infiltration of inflammatory cells, particularly CD8+ $\mathrm{T}$ cells, in the recovered BAL fluid in both CXCR3-/- mice and WT mice; however, there was no significant difference between the two genotypes (data not shown). 


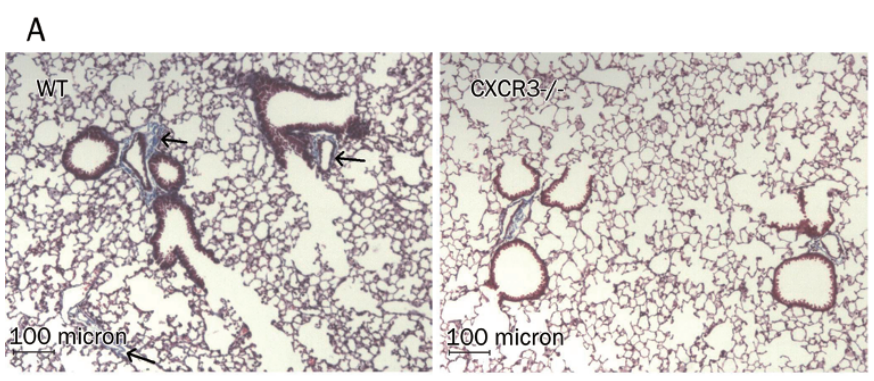

B

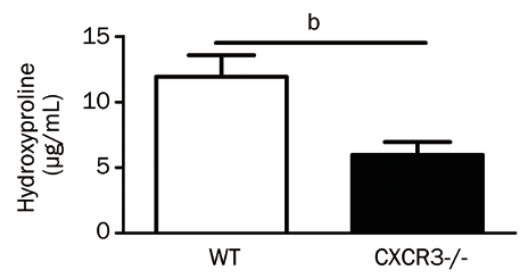

C

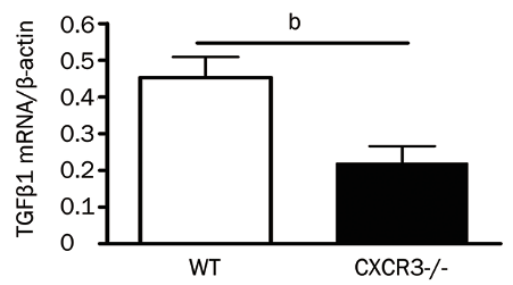

Figure 4. Effect of CXCR3 on airway remodeling at three days after the last CS exposure. (A) Histological appearance in CXCR3-/- and WT mice (magnification $\times 40$ ); the arrows point to the collagen deposition around small airways and vessels in WT mice, $n=5$ mice/group. (B) Hydroxyproline content of lung tissue in CXCR3-/- and WT mice, $n=6$ mice/group. (C) Comparison of mRNA expression of TGF $\beta 1$ in lung homogenates between in CXCR3-/- and WT mice, $n=8$ mice/group. Results are expressed as mean \pm SEM. ${ }^{\mathrm{b}} P<0.05$.

A

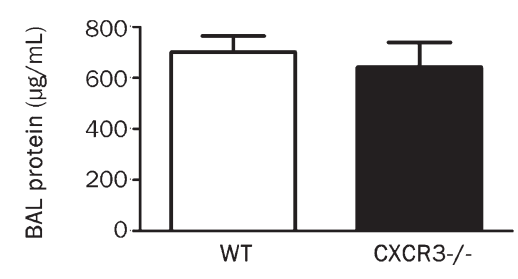

B

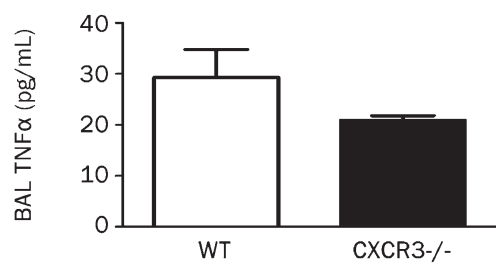

Figure 5. Effect of CXCR3 deficiency on protein leakage and TNF $\alpha$ concentration in BAL fluid at three days after the three-day CS insult. (A) Protein concentration in BAL fluid, $n=5$ mice/group. (B) TNF $\alpha$ content in BAL fluid, $n=6$ mice/group. Results are expressed as mean \pm SEM.

\section{Discussion}

Pulmonary tissue damage represented by enlarged airspace in lung tissue has been postulated to result from an imbalance in protease/antiprotease content, in which proteolysis is mediated by elastin-degrading enzymes; for example, MMP2, MMP9, and MMP12 are over-activated ${ }^{[22,24]}$. MMP12-deficient mice were shown to be resistant to developing emphysema after long-term CS exposure ${ }^{[25]}$. In the current study, we found that Lm values, reflecting the enlargement of airspaces, were significantly greater in WT mice than in CXCR3-/- mice at three days after short-term CS exposure $(40.3 \pm 2.4 \mu \mathrm{m} v \mathrm{~s}$ $30.1 \pm 0.9 \mu \mathrm{m}, P<0.01)$. Furthermore, we have observed an over-expression of MMP2 and MMP12 at the mRNA level at three days after the last CS exposure in WT mice. This reflects inappropriate activation of these enzymes even upon short-term CS insult, whereas expression of these enzymes in CXCR3-/- mice mRNA was not as high as that in WT mice. Under pathological conditions, expression of MMPs is regulated by cytokines and chemokines, which are substrates for MMPs. Previous studies have shown that CXCL10/IP-10 and CXCL9/Mig are secreted from lung lymphocytes in patients with emphysema, specifically up-regulating MMP12 and thus favoring a proteolytic microenvironment that facilitates lung destruction ${ }^{[24,26]}$. Elias and colleagues have provided evidence that these enzymes may be regulated by proximal immune events through a Th1 cell- or IFN $\gamma$-dependent manner ${ }^{[26]}$. T cells, particularly CD8+ T cells, accumulate in the lungs of patients with COPD and generate signals such as CXCL10/ IP-10 that promote MMP12 production by macrophages ${ }^{[27,28]}$. Moreover, CXCR3 expressed by human T cells and macrophages is required for MMP12 secretion in response to IP-10/Mig stimulation ${ }^{[24]}$. Our previous data from CXCR3 knockout mice suggested that attenuated pulmonary acute inflammation in CXCR3 knockout mice induced by short-term exposure of CS was attributed to lesser recruitment of CD8+ T cells into lung tissue and lesser release of its ligand, CXCL10/ IP-10 ${ }^{[15,16]}$. Notably, we observed that only CXCL10/IP-10 remained significantly elevated in both BAL fluid and lung homogenates at three days after the last CS exposure (BAL fluid: $19.3 \pm 1.4 \mathrm{pg} / \mathrm{mL}$ vs $24.8 \pm 1.6 \mathrm{pg} / \mathrm{mL}, P<0.05$; lung homogenates: $76.6 \pm 7.0 \mathrm{pg} / \mathrm{mL}$ vs $119.5 \pm 15.9 \mathrm{pg} / \mathrm{mL}, P<0.05)$, and a prominent inflammatory response was absent (Figure 1A) in this present study. Therefore, these findings may implicate MMPs (MMP2 and MMP12) and effector cytokines (IFNY and CXCL10/IP-10) as potential mediators coordinately driving smoking-induced lung destruction. TIMP3 is the only TIMP known to be associated with human diseases ${ }^{[2]}$ and has an inhibitory effect on MMPs. Mice deficient in TIMP3 demonstrated spontaneous airspace enlargement ${ }^{[30]}$. In support of the classical view that an imbalance of MMPs and TIMPs leads to collagen destruction, we also found that TIMP3 was significantly less induced in WT mice compared to CXCR3-/mice at the mRNA level. The exact mechanism of how TIMP3 expression is regulated by CXCR3 and/or CXCL10 under CS challenge remains unclear. 
Airway remodeling is a characteristic of COPD and is associated with irreversible airflow limitation ${ }^{[2]}$. We have demonstrated that airway remodeling is less profound in CXCR3-/mice after CS exposure, as reflected by less peribronchial deposition of collagen (Figure 4A) and less hydroxyproline content in lungs $(6.0 \pm 1.0 \mu \mathrm{g} / \mathrm{mL}$ vs $12.0 \pm 1.6 \mu \mathrm{g} / \mathrm{mL}, P<0.05)$. We attempted to explore the mechanism that mediates this process. In this study, we found increased expression of TGF $\beta 1$ at the mRNA level in WT mice exposed to CS and not in CXCR3-/- mice. The functional importance of TGF $\beta 1$ in tissue repair has been well described, and it is recognized as a potent inducer of collagen production ${ }^{[31]}$. Evidence from human studies and animal models indicates that TGF $\beta 1$ plays a pivotal role in mediating pathogenic changes by stimulating fibroblasts to synthesize a large amount of extracellular matrix proteins. TGF $\beta 1$ is expressed in a variety of cells including fibroblasts, macrophages, epithelial, and endothelial cells ${ }^{[31]}$. Although it is generally thought that airway remodeling is due to an abnormal response to repeated inflammatory stimulation caused by CS and an aberrant repair induced by inflammatory cells, it is alternatively accepted that CS directly causes excessive production of growth factors leading to smooth muscle hypertrophy and fibrosis formation in the airway, independent of the inflammatory response ${ }^{[31]}$. Wang and colleagues recently reported that elevated TGF1 expression drives airway remodeling in tracheal explants even after a single CS exposure $^{[32]}$. Consistent with these observations, we did not demonstrate a significant difference in protein leakage and TNFa concentration in BAL fluid between CXCR3-/- and WT mice. Taken together, we carefully put forward the hypothesis that airway remodeling caused by CS challenge could be mediated via TGF $\beta 1$ released by epithelial cells insulted by CS directly. How TGF $\beta 1$ is regulated in the presence of CXCR3 and CXCL10/IP-10 should be further investigated.

Interactions between MMPs and TGF $\beta$ have been suggested to explain the contradictory events in destructive pulmonary architecture in parenchyma and thickened bronchial walls. In this study, our data demonstrate that over-activation of TGF $\beta 1$ together with MMP2 and MMP12 expression at the mRNA level in WT mice, which is partly in accordance with the previous reports that increased MMPs at the protein level were seen in patients with emphysema ${ }^{[27,28]}$, have tissue destructive and fibrotic effects depending on the location (either in parenchyma or in airways) ${ }^{[3]]}$. It should be pointed out that the current study was based on a short-term exposure model. The exact role of CXCR3 and its ligands in CS-induced chronic lung pathology deserves further investigation.

In summary, we have shown that lung tissue destruction and airway remodeling are partially, but significantly, alleviated in CXCR3-/- mice at three days after short-term CS exposure. Our data further show that, possibly independent of an inflammatory response, CXCL10/IP-10 in combination with MMPs (mainly MMP2 and MMP12) could promote extracellular matrix collagen deposition in the airway, causing subepithelial and lung tissue damage. This study may suggest that early targeting of the CXCR3-CXCL10 axis might be benefi- cial for halting CS-mediated lung tissue damage and airway remodeling.

\section{Acknowledgements}

We acknowledge Professor Craig GERARD for providing the CXCR3 knockout mice and the staff of the Animal CenterPUMC for caring for the animals; in particular, we acknowledge Ms Hui-min ZHAO's kind help. We gratefully acknowledge Professor Kian Fan CHUNG for the critical comments. We thank Dr Zhi-yong LIANG's help in evaluating the pathological analysis.

This work was supported by grants from the National Natural Sciences Foundation of China (№ 30470767), Beijing Natural Sciences Foundation (№ 7072063), and the Education Ministry of China New Century Excellent Talent (NCET 06-0156).

\section{Author contribution}

Li NIE, Zhen-jia LIU, and Ruo-lan XIANG performed all of the experiments. Wei-xun ZHOU and Yu XIAO carried out the pathological analysis. Bao LU helped with designing and drafting the manuscript. Bao-sen PANG provided the smoke generator and technical help. Jin-ming GAO designed and supervised the experiment and drafted the manuscript.

\section{References}

1 Pauwels RA, Rabe KF. Burden and clinical features of chronic obstructive pulmonary disease (COPD). Lancet 2004; 364: 613-20.

2 Chung KF, Adcock IM. Multifaceted mechanisms in COPD: inflammation, immunity, and tissue repair and destruction. Eur Respir J 2008; 31: 1334-56.

3 Niewoehner DE, Kleinerman J, Rice DB. Pathologic changes in the peripheral airways of young cigarette smokers. N Engl J Med 1974; 291: 755-8.

4 Bosken CH, Wiggs BR, Pare PD, Hogg JC. Small airway dimensions in smokers with obstruction to airflow. Am Rev Respir Dis 1990; 142: 563-70.

5 Gelb AF, Hogg JC, Muller NL, Schein MJ, Kuei J, Tashkin DP, et al. Contribution of emphysema and small airways in COPD. Chest 1996; 109: 353-9.

6 Hogg JC, Chu F, Utokaparch S, Woods R, Elliott WM, Buzatu L, et al. The nature of small-airway obstruction in chronic obstructive pulmonary disease. N Engl J Med 2004; 350: 2645-53.

7 Bracke KR, D'Hulst A I, Maes T, Moerloose KB, Demedts IK, Lebecque $\mathrm{S}$, et al. Cigarette smoke-induced pulmonary inflammation and emphysema are attenuated in CCR6-deficient mice. J Immunol 2006; 177: 4350-9.

8 Bracke KR, D'Hulst A I, Maes T, Demedts IK, Moerloose KB, Kuziel WA, et al. Cigarette smoke-induced pulmonary inflammation, but not airway remodelling, is attenuated in chemokine receptor 5-deficient mice. Clin Exp Allergy 2007; 37: 1467-79.

9 Ma B, Kang MJ, Lee CG, Chapoval S, Liu W, Chen Q, et al. Role of CCR5 in IFN-gamma-induced and cigarette smoke-induced emphysema. J Clin Invest 2005; 115: 3460-72.

10 Costa C, Rufino R, Traves SL, Lapa ESJR, Barnes PJ, Donnelly LE. CXCR3 and CCR5 chemokines in induced sputum from patients with COPD. Chest 2008; 133: 26-33.

11 Thatcher TH, McHugh NA, Egan RW, Chapman RW, Hey JA, Turner CK, et al. Role of CXCR2 in cigarette smoke-induced lung inflammation. Am J Physiol Lung Cell Mol Physiol 2005; 289: L322-8. 
12 Maeno T, Houghton AM, Quintero PA, Grumelli S, Owen CA, Shapiro $\mathrm{SD} . \mathrm{CD}^{+} \mathrm{T}$ Cells are required for inflammation and destruction in cigarette smoke-induced emphysema in mice. J Immunol 2007; 178 : 8090-6.

13 D'Ambrosio D, Mariani M, Panina-Bordignon P, Sinigaglia F. Chemokines and their receptors guiding $T$ lymphocyte recruitment in lung inflammation. Am J Respir Crit Care Med 2001; 164: 1266-75.

14 Saetta M, Mariani M, Panina-Bordignon P, Turato G, Buonsanti C, Baraldo $\mathrm{S}$, et al. Increased expression of the chemokine receptor CXCR3 and its ligand CXCL10 in peripheral airways of smokers with chronic obstructive pulmonary disease. Am J Respir Crit Care Med 2002; 165: 1404-9.

15 Nie L, Xiang RL, Liu Y, Zhou WX, Jiang L, Lu B, et al. Acute pulmonary inflammation is inhibited in CXCR3 knockout mice after short-term cigarette smoke exposure. Acta Pharmacol Sin 2008; 29: 1432-9.

16 Nie L, Xiang R, Zhou W, Lu B, Cheng D, Gao J. Attenuation of acute lung inflammation induced by cigarette smoke in CXCR3 knockout mice. Respir Res 2008; 9: 82.

17 Hancock WW, Lu B, Gao W, Csizmadia V, Faia K, King JA, et al. Requirement of the chemokine receptor CXCR3 for acute allograft rejection. J Exp Med 2000; 192: 1515-20.

18 Wright JL, Churg A. Short-term exposure to cigarette smoke induces endothelial dysfunction in small intrapulmonary arteries: analysis using guinea pig precision cut lung slices. J Appl Physiol 2008; 104: 1462-9.

19 Churg A, Zay K, Shay S, Xie C, Shapiro SD, Hendricks R, et al. Acute cigarette smoke-induced connective tissue breakdown requires both neutrophils and macrophage metalloelastase in mice. Am J Respir Cell Mol Biol 2002; 27: 368-74.

20 Moore BB, Paine R 3rd, Christensen PJ, Moore TA, Sitterding S, Ngan $\mathrm{R}$, et al. Protection from pulmonary fibrosis in the absence of CCR2 signaling. J Immunol 2001; 167: 4368-77.

21 Morris DG, Sheppard D. Pulmonary emphysema: when more is less. Physiology (Bethesda) 2006; 21: 396-403.
22 Wang Z, Zheng T, Zhu Z, Homer RJ, Riese RJ, Chapman HA Jr, et al. Interferon gamma induction of pulmonary emphysema in the adult murine lung. J Exp Med 2000; 192: 1587-600.

23 Shapiro SD. Proteolysis in the lung. Eur Respir J Suppl 2003; 44: 30s-32s.

24 Grumelli S, Corry DB, Song LZ, Song L, Green L, Huh J, et al. An immune basis for lung parenchymal destruction in chronic obstructive pulmonary disease and emphysema. PLoS Med 2004; 1: e8.

25 Hautamaki RD, Kobayashi DK, Senior RM, Shapiro SD. Requirement for macrophage elastase for cigarette smoke-induced emphysema in mice. Science 1997; 277: 2002-4.

26 Elias JA, Kang MJ, Crothers K, Homer R, Lee CG. State of the art. Mechanistic heterogeneity in chronic obstructive pulmonary disease: insights from transgenic mice. Proc Am Thorac Soc 2006; 3: 494-8.

27 Finlay GA, O'Driscoll LR, Russell KJ, D’Arcy EM, Masterson JB, FitzGerald MX, et al. Matrix metalloproteinase expression and production by alveolar macrophages in emphysema. Am J Respir Crit Care Med 1997; 156: 240-7.

28 Molet S, Belleguic C, Lena H, Germain N, Bertrand CP, Shapiro SD, et al. Increase in macrophage elastase (MMP-12) in lungs from patients with chronic obstructive pulmonary disease. Inflamm Res 2005; 54 : 31-6.

29 Woessner JF Jr. That impish TIMP: the tissue inhibitor of metalloproteinases-3. J Clin Invest 2001; 108: 799-800.

30 Leco KJ, Waterhouse P, Sanchez OH, Gowing KL, Poole AR, Wakeham $A$, et al. Spontaneous air space enlargement in the lungs of mice lacking tissue inhibitor of metalloproteinases-3 (TIMP-3). J Clin Invest 2001; 108: 817-29.

31 Postma DS, Timens W. Remodeling in asthma and chronic obstructive pulmonary disease. Proc Am Thorac Soc 2006; 3: 434-9.

32 Wang RD, Wright JL, Churg A. Transforming growth factor-beta1 drives airway remodeling in cigarette smoke-exposed tracheal explants. Am J Respir Cell Mol Biol 2005; 33: 387-93. 